\title{
An Empirical Analysis of the Contribution of Mining Sector to Economic Development in Nigeria
}

\author{
David, Oladipo Olalekan \\ University of South Africa, Pretoria, South Africa \\ Noah, Oluwashina Afees \\ Kwara State Polytechnic, Ilorin, Nigeria \\ Agbalajobi, Sunday Ayodele \\ Kwara State Polytechnic, Ilorin, Nigeria
}

\section{INTRODUCTION}

Nigeria is richly endowed with vast natural resources that are widely distributed across the country among these are;solid minerals, petroleum and natural gas. About fifty solid minerals have been discovered in five hundred locations in the country (Alison-Madueke, 2009).As a result of this, mining is done virtually in all the states of the federation.Mining industries have been viewed as key drivers of economic growth and the development process, as lead sectors that drive economic expansion which can lead to higher levels of social and economic well being (Bridge, 2008).Coal and tin ranked high as Nigeria's foreign exchange earners during the colonial period and after the country's independence in 1960, other minerals such as limestone, gold, marble, clay etc were mined to a lesser degree mainly for local consumption (Adekeye, 1999).

Therefore, the discovery of crude oil in 1956, oil glut of the 1970s and early 1980s have drastically affected the solid minerals industry to an extent that the overall contribution of mining to the national Gross Domestic Product (GDP) has been declining and was about $0.5 \%$ in 2009. This has led Nigerian economy to become a mono product economy and hence vulnerable to international oil politics and its repercussions. The domineering role of oil did not allow past governments to attend to global challenges that evolved in the development of solid minerals. No doubt, the petrodollar from these oil booms led to the neglect of these huge economic potential. Thismade Nigeria to experience the "Dutch disease" reflected by an appreciating exchange rate, subsidize imports whilediscouraging non-oil exports; which in Nigeria's case includes the solid mineral sector which hitherto 
the discovery ofcrude oil was a major contributor to economic growth (Martin and Subramanian, 2003).

However, the collapse of oil price, increasing unemployment among youth, the restiveness in the Niger Delta, the global economic recession among others have combined to force government on the need to diversify the revenue base of the Nigerian economy. Thus in addition to developing other sectors such as agriculture, it is believed that mining sector can also make significant contribution to the economic growth and development of the country by reducing the overdependence on oil as a major source of foreign exchange earner. In realizing this, several efforts have also been employed by successful Nigerian governments in the past to establish some agencies in an attempt to revamp the sector among these are; The Nigerian Mining Corporation (NMC), The Nigeria Coal Corporation (NCC), The Nigeria Uranium Mining Corporation (NUMC),The Associated Ores Mining Company (AOMN). However, it is obvious that these agencies were created for specific purposes and their achievements have been minimal mainly because of lack of adequate funding, skilled manpower and poor economic conditions (Adekeye, 1999). Among the recent efforts made by the government to harness the potentials of mining for the enhancement of its contribution to national earning is the creation of a Mining Cadastre System in mineral title administration, The Mines Inspectorate Office, responsible for the enforcement of legislation and collection of royalties, The Mining Environmental Compliance Department responsible for all environmental related mining issues and The Artisanal and Small Scale Mining Department, responsible for the organization and encouragement of small scale miners.

Though Nigeria has great mining potentials for development of her economy but its present contribution to the GDP at $0.5 \%$ is still low and unfavourable compare to its sub-Saharan neighbours(such as Botswana, DR Congo, Namibia among others) in respect of GDP and export value generated from solid minerals. The sector has been constrained mainly by the insufficient exploration investment which has led to underperformance of the sector and consequent loss of economic opportunities. The aim of this paper therefore is to investigate the contribution of mining sector to the economic development in Nigeria even with the several years of neglect by the public and private sectors. The specific objective is to examine theproblems militating against the mining sector in Nigeria and the strategies for its transformation of the economy towards diversification of Nigerian economy. The rest of this paper is divided into four parts; part II contains the conceptual framework and review of literature, part III contains the methodological issues, presentation and discussion of results is contained in part IV while part $\mathrm{V}$ concludes and recommends. 


\section{CONCEPTUAL FRAMEWORK AND LITERATURE REVIEW}

\subsection{Conceptual Issues}

Mining, minerals and metals are important to the economic and social development of many countries. Minerals can either be extracted from the surface of the earth or from deep in the earth. The process of extracting minerals from open mines is termed as quarrying while the process of extracting minerals from shaft mines is termed as mining. For example, in case of limestone and marble stones quarrying processes take place, whereas mining is done in case of iron, coal, gold etc (Jhingan \& Sharma, 2008). The Nigeria mining sector has the potential of driving the nation's economic growth (compared to its current contribution of less than $1.0 \%$ of GDP). Growth of the sector will diversify the national economy and minimize over- dependence on Oil and Gas as primary sources of revenue. Upstream and downstream activities of the sector will greatly promote sustainable economic growth. Rights to ownership of mineral resources is held by the Nigeria government, which grants titles to organizations to explore, mine and sell mineral resources. Mining regulation is handled by the Ministry of Solid Mineral Development established in 1995, which oversees the management of all mineral resources. Mining law is codified in the Federal Minerals and Mining Act of 1999 with a reform in 2005 and 2007. The domestic mining industry is underdeveloped, leading to Nigeria having to import minerals that could be produced domestically, many factors are responsible for this, this range from the overdependence of the Nigerian economy on oil and gas sector which has led to the neglect of other critical sectors of the economy, to the inadequate legislation and poor law enforcement which has made the sector to be largely informal, inefficient state operations, environmental degradation, jurisdictional conflicts between federal and state governments, depleted surface alluvial deposits( especially tin) among others (Alison-Madueke, 2009).

Economic development encompasses progress in providing livelihood on a sustainable basis, access to education and basic healthcare for the majority of the population (Belshaw and Livingstone, 2003). The meaning of the term 'development' becomes clearer with the understanding of the term 'economic growth'. Economic growth means the increase overtime in country's real output per capital. Economic growth and development are complementary, because one makes the other possible. They are also alternating processes that occur sequentially. Economic growth is an increase in output while economic development is a structural change, for example technology or legal. Growth expands the economy, while development must lead to more equal distribution of income and wealth (Malizia \& Feser, 2002). 


\subsection{Empirical Review of Literature}

The impact of mining of solid minerals on domestic economies has been examined fromdifferent perspectives. There is for instance the structuralist thesis which attributes the underperformance of such economies to the role of the Multinational Corporations. Proponents like Girran $(1970 ; 1971)$, Evans (1975) submit that with reference to Jamaica, less than $3 \%$ of the total value-added created by the bauxitealuminium production chain accrued to the country. This was attributed to a combination of the aluminium, Multinational Corporations vertically integrated production strategy and oligopolistic market structure dominated by six large corporations. It is further arguedthat the Multinational Corporations, set prices so that they would reduce their tax liabilities through transferpricing. Evans' (1975) findings in the study on Brazil are similar to Girran's.

Another explanation of the linkages of mining to the domestic economy is the "stable thesis". This derives from the proposition that the impact of mineral rent on the host economies is mixed. According to this thesis, rent from successive mining activities has played a role in the growth of such developed advanced countries as the USA, Canada and Australia. Governments have a number of ways of distributing benefits locally. Specifically, Reynolds(1979) notes that profit from copper funded development in 17th century Sweden, and similarly gold in Australia and South Africa. Proponents of this thesis further point out that Britain's property is partly attributed to the rents earned by the exploitation of minerals from the colonies. The gist of the stable thesis is that host economies need to enunciate policies that will enable them to harness the mining rents for the development of their economies. Akey method is a more deliberate sharing of fiscal revenues among different levels of government and other stakeholders. It is noted that in Peru, the mining law provides for a fixed percentage of the mineral revenues collected by central government is to be paid to regional authorities. However, due to 'fiscal difficulties' the central government has delayed the transfer of funds. Very few countries have established provisions for the distribution of funds beyond the national level.

Among the recent studies on the impact of mining of the solid minerals is Roderick (2001), in his study of mining and economic sustainability, employing mainly qualitative analysis. He concluded that through appropriate responses to the challenges of mining and economic development, the benefits of mining can be sustained, even when a mine or a mining community inevitably declines as the ore runs out. Mineral wealth lives on, but in other forms such as in educated and healthy people, efficient and fair social institutions, and man-made physical capital but mining and minerals can be a curse if the challenges are not met. 
Adeniyi et al(2013), in their analysis on the legal regime for exploring solid minerals for economic growth in Nigeria, employing mainly qualitative analysis. The study revealed that the solid mineral sector remains crucial to economic development, wealth creation and poverty alleviation in any nation that is blessed with such mineral deposits and concluded that Nigeria government should adopt best practices and mechanisms that have been used by different countries to formalize and regulate mining explorations in order to attain sustainable development in the mining sector in Nigeria.

Akongwale et al (2013) in their analysis on the role of solid minerals on economic diversification in Nigeria, employing both qualitative and quantitative (descriptive) analysis, the study shows that the solid mineral sector in Nigeria has the potential to contribute immensely to the economy of Nigeria. Specifically, it reveals that the development of the solid mineral sector could help to combat poverty in Nigeria via job creation; especially, given its forward linkage with other sectors of the economy. Most importantly, it could help alleviate some of the problems associated with "enclave" nature of the Nigerian economy that has for too long being vulnerable to fluctuations in global oil prices. And concluded that the realization of these potentials need the strengthening of Nigeria's existing solid mineral development policy and creation of an enabling environment by the government for the private sector to take the lead in the sector.

Adekeye (2010) in his study on the impact of conflict on mining in Nigeria revealed that there is much more to be gained from the development of mining sector than is usually organized and there is very much to lose from the nondevelopment of the sector.Agba (2007) in his study on economic analysis of natural resources sustainability for the mining sector component in Nigeria, employing both qualitative and quantitative (descriptive) analysis, the study revealed that Nigeria stands to benefit from the development of solid minerals sector and concluded that the government must provide enabling environment for the private sector investment in mining.

Finally, from the review of the literature above, almost all the studies employed mainly qualitative and descriptive analysis in their research work as against this current research which focus on the quantitative assessment of the contribution of mining sector to the economic development in Nigeria towards diversification of Nigerian economy through mainly quantitative and time series data analysis. 


\section{METHODOLOGY}

Empirical studies have shown that mining sector has been viewed as one of the key drivers of economic growth and development (Evans, 1975; Reynolds, 1979; Roderick, 2001; Agba, 2007; Bridge, 2008; Akongwale et al, 2013). These literatures uphold the sector theory as opined by (Hoyt, 1939) that over time the relative share of production in each major sector will change in the region. The economy is divided into three aggregated sectors: primary (agriculture, forestry, and fisheries), secondary (manufacturing, mining) and tertiary (trade and services). Due to the income elasticity of demand for primary, secondary, and tertiary products, the region becomes specialized in primary, then secondary, then tertiary products. This study follows the footpath of these literatures with modification by determining the short and long run equilibrium in economic development through the impact of the key sectors in the economy. The key sectors are identified as crude petroleum and gas, solid mineral, manufacturing and agriculture. The study harnessed time series data to evaluate the impact of the specified key sectors; crude petroleum and gas, solid mineral, manufacturing and agriculture on the economic development proxied by per capita income. The scope of the study includes $1960-$ 2012, which are fifty three observations for each of the indicators.

\subsection{Model Specification}

As earlier opined that short and long run equilibrium of economic development will be determined, thus, the model for this study is Error Correction Model (ECM) and it is based on the assumptions that: crude petroleum and gas, solid mineral, manufacturing and agriculture determine economic development in Nigeria,proper exploitation and utilization determine the output of mining and production in all the sectors, there is no wastage of resources. We therefore postulate the relationship between per capita income and mining activities as;

$$
P I=f(P N G, S M, M F, A G R)
$$

The equation (1) shows the functional relationship between the Per Capita Income (PI), Value of Crude Petroleum and Gas (PNG), Value of Solid Mineral (SM), Value of Manufacturing (MF) and Value of Agriculture (AGR). These specified variables are one way or the other related to the mining sector since soil exploration is involved in one stage or the other of the productions.

Stating the model linearly;

$$
P I_{t}=\Psi_{0}+\Psi_{l} P N G_{t}+\Psi_{2} S M_{t}+\Psi_{3} M F_{t}+\Psi_{4} A G R_{t}+\mu_{t}
$$


And, the relationships that exist between the regressand (Per capita Income) and the regressors (Value of Crude Petroleum and Gas, Value of Solid Mineral, Value of Manufacturing and Value of Agriculture) are measured at present period. And, $\Psi_{0}=$ intercept, $\Psi_{1}-\Psi_{4}=$ partial slopes and $\mu_{\mathrm{t}}=$ unobserved components and $\Psi_{1}-$ $\Psi_{4}$ are expected to be positive based on the a priori expectation i.e.

$\frac{\partial P I_{t}}{\partial P N G_{t}}>0 ; \frac{\partial P I_{t}}{\partial S M_{t}}>0 ; \frac{\partial P I_{t}}{\partial M F_{t}}>0 \& \frac{\partial P I_{t}}{\partial A G R_{t}}>0$, therefore, $\Psi_{l}-\Psi_{4}>0$

The Classical Least Squares (CLS) techniques are employed to estimate the parameters of the model in which the assumptions of classical least squares technique is adhere to strictly.

The study's data are time series, stationarity test is inevitable, and therefore, the sationarity test follows the Augmented Dickey-Fuller (ADF) unit root test. The ADF models for the research variables are;

$$
\begin{aligned}
& \Delta P I_{t}=\beta_{11}+\beta_{12} t+\delta_{1} P I_{t-1}+\Sigma \beta_{13} \Delta P I_{t-i}+\varepsilon_{1 t} \\
& \Delta P N G_{t}=\beta_{21}+\beta_{22} t+\delta_{2} P N G_{t-1}+\Sigma \beta_{23} \Delta P N G_{t-i}+\varepsilon_{2 t} \\
& \Delta S M_{t}=\beta_{31}+\beta_{32} t+\delta_{3} S M_{t-1}+\Sigma \beta_{33} \Delta S M_{t-i}+\varepsilon_{3 t} \\
& \Delta M F_{t}=\beta_{41}+\beta_{42} t+\delta_{4} M F_{t-1}+\Sigma \beta_{43} \Delta M F_{t-i}+\varepsilon_{4 t} \\
& \Delta A G R_{t}=\beta_{51}+\beta_{52} t+\delta_{5} A G R_{t-1}+\Sigma \beta_{53} \Delta A G R_{t-i}+\varepsilon_{5 t}
\end{aligned}
$$

These models are to validate the stationarity of the time series data use for this study, if the data are not stationarity at level, there will be a need to transform the data by order of integration. Thus, cointegration test will validate the short run equilibrium of the data. The long run equation is stated as equation (3.2) i.e. $\mathrm{PI}=$ $\Psi_{0}+\Psi_{1} P N G_{t}+\Psi_{2} S M_{t}+\Psi_{3} M F_{t}+\Psi_{4} A G R_{t}+\mu_{t}$

Transforming this model will yield introduction of first difference $(\Delta)$ and lag of error term by one period to measure the rate of adjustment in the equilibrium of the model. The lag of error term by one period is the error correction mechanism (ECM) that measures the rate of adjustment of the variables from long run to short run. The ECM was used by Engle and Granger to correct disequilibrium for this study to tie the short run behavior of economic growth to its long run. Stating the short run model for economic development,

$$
\begin{array}{r}
P I_{t}=\Psi_{0}+\Psi_{l} P N G_{t}+\Psi_{2} S M_{t}+\Psi_{3} M F_{t}+\Psi_{4} A G R_{t}+\mu_{t} \\
\mu_{t}=P I_{t}-\Psi_{0}-\Psi_{1} P N G_{t}-\Psi_{2} S M_{t}-\Psi_{3} M F_{t}-\Psi_{4} A G R_{t}+\Psi_{5} t
\end{array}
$$

Taking lag of error term;

$$
\mu_{t-1}=P I_{t-1}-\Psi_{0}-\Psi_{1} P N G_{t-1}-\Psi_{2} S M_{t-1}-\Psi_{3} M F_{t-1}-\Psi_{4} A G R_{t-1}
$$

Transforming (3.2) to a Cointegration and Error Correction Mechanism; 


$$
\begin{array}{r}
\Delta P I_{t}=\Psi_{0}+\Psi_{1} \Delta P N G_{t}+\Psi_{2} \Delta S M_{t}+\Psi_{3} M F_{t}+\Psi_{4} \Delta A G R_{t}+\left(P I_{t-1}-\Psi_{0}-\Psi_{1} P N G_{t-1^{-}}\right. \\
\left.\Psi_{2} S M_{t-I^{-}} \Psi_{3} M F_{t-1}-\Psi_{4} A G R_{t-1}\right)+\theta_{l t}
\end{array}
$$

Since; $\mu_{t-1}=P I_{t-1}-\Psi_{0}-\Psi_{1} P N G_{t-1}-\Psi_{2} S M_{t-1}-\Psi_{3} M F_{t-1}-\Psi_{4} A G R_{t-1}$

Therefore,

$$
\Delta P I_{t}=\Psi_{0}+\Psi_{1} \Delta P N G_{t}+\Psi_{2} \Delta S M_{t}+\Psi_{3} M F_{t}+\Psi_{4} \Delta A G R_{t}+\lambda \mu_{t-1}+\theta_{l t}
$$

And, equation (3.11) is the Cointegration and Error Correction Mechanism, $\lambda$ is the

\begin{tabular}{|c|c|c|c|c|}
\hline $\begin{array}{c}\text { Variab } \\
\text { le }\end{array}$ & Indicator & Variable Definition & $\begin{array}{l}\text { Unit of } \\
\text { Measure } \\
\text { ment }\end{array}$ & Source of Data \\
\hline $\mathrm{PI}_{\mathrm{t}}$ & Per capita income & $\begin{array}{l}\text { GDP per capita as a proxy for } \\
\text { Economic Development }\end{array}$ & $\begin{array}{l}\text { Thousand } \\
\text { inDollar }\end{array}$ & $\begin{array}{c}\text { World Bank } \\
\text { Indicators, } 2013\end{array}$ \\
\hline $\mathrm{PNG}_{\mathrm{t}}$ & $\begin{array}{l}\text { Value of Crude } \\
\text { Petroleum and } \\
\quad \text { Gas }\end{array}$ & $\begin{array}{l}\text { Contribution of Crude } \\
\text { Petroleum and Gas to the } \\
\text { GDP as a proxy for Mining } \\
\text { operation of Oil and Gas }\end{array}$ & $\begin{array}{l}\text { Million in } \\
\text { Naira }\end{array}$ & $\begin{array}{c}\text { Central Bank of } \\
\text { Nigeria Statistical } \\
\text { Bulletin, } 2013\end{array}$ \\
\hline $\mathrm{SM}_{\mathrm{t}}$ & $\begin{array}{l}\text { Value of Solid } \\
\text { Mineral }\end{array}$ & $\begin{array}{l}\text { Contribution of Solid Mineral } \\
\text { to the GDP as a proxy for } \\
\text { Mining operation of coal, iron } \\
\text { ore and Quarrying }\end{array}$ & $\begin{array}{l}\text { Million in } \\
\text { Naira }\end{array}$ & $\begin{array}{c}\text { Central Bank of } \\
\text { Nigeria Statistical } \\
\text { Bulletin, } 2013\end{array}$ \\
\hline $\mathrm{MF}_{\mathrm{t}}$ & $\begin{array}{c}\text { Value of } \\
\text { Manufacturing }\end{array}$ & $\begin{array}{l}\text { Contribution of } \\
\text { Manufacturing to the GDP as } \\
\text { a proxy for Mining operation } \\
\text { of Lime stone, cement etc. }\end{array}$ & $\begin{array}{l}\text { Million in } \\
\text { Naira }\end{array}$ & $\begin{array}{c}\text { Central Bank of } \\
\text { Nigeria Statistical } \\
\text { Bulletin, } 2013\end{array}$ \\
\hline $\mathrm{AGR}_{\mathrm{t}}$ & $\begin{array}{c}\text { Value of } \\
\text { Agriculture }\end{array}$ & $\begin{array}{l}\text { Contribution of Agriculture to } \\
\text { the GDP as a proxy for } \\
\text { Mining operation of Forestry, } \\
\text { cropping etc. }\end{array}$ & $\begin{array}{l}\text { Million in } \\
\text { Naira }\end{array}$ & $\begin{array}{c}\text { Central Bank of } \\
\text { Nigeria Statistical } \\
\text { Bulletin, } 2013\end{array}$ \\
\hline
\end{tabular}
parameter employed to assess the time of adjustment of equilibrium.

Tab. 1 - Summary of Dataset

\subsection{Hypothesis Statement:}

$\mathrm{H}_{0}=$ Mining sector does not have contribution to economic development in Nigeria $\mathrm{H}_{1}=$ Mining sector have contribution to economic development in Nigeria 


\section{PRESENTATION OF THE RESULTS AND DATA ANALYSIS}

\subsection{Data Trend}

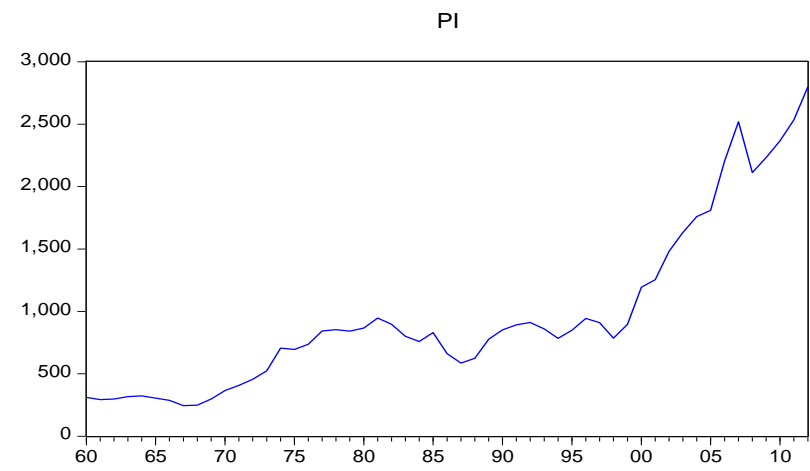

Figure. 1a

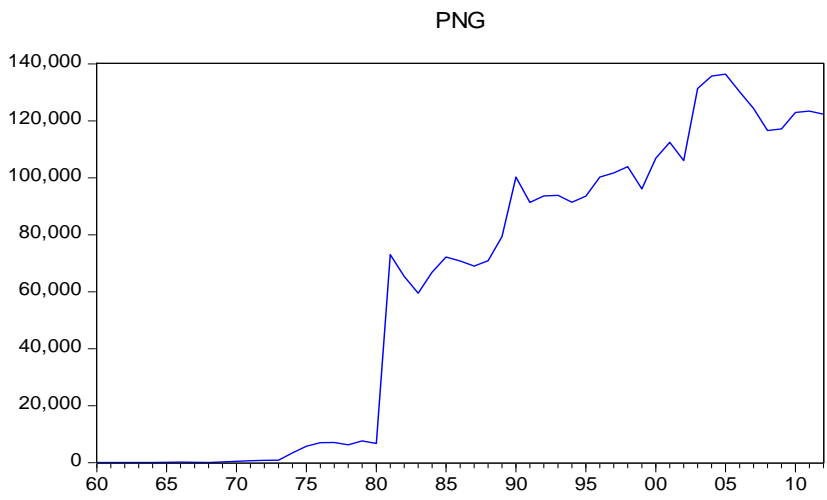

Figure. $1 b$

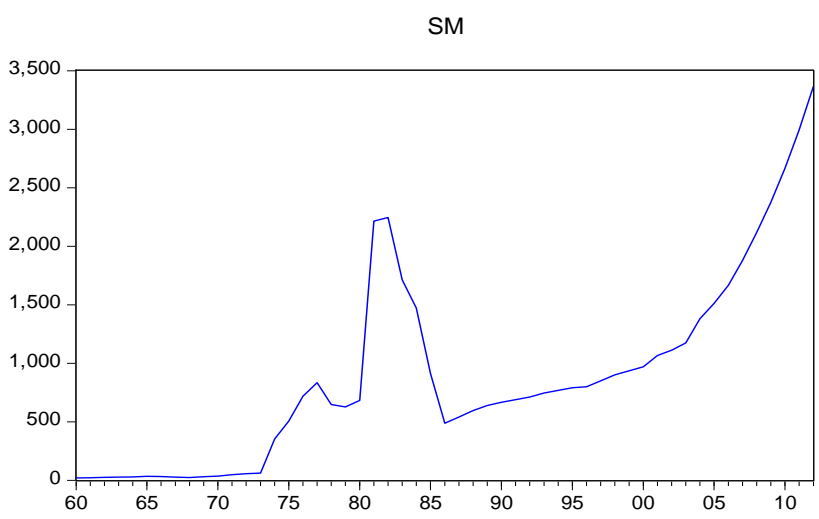

Figure. 1c 


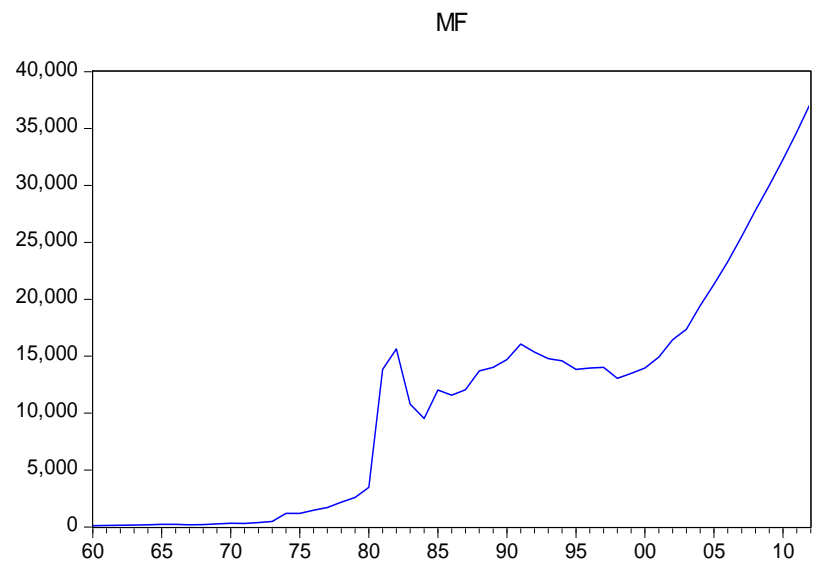

Figure . 1d

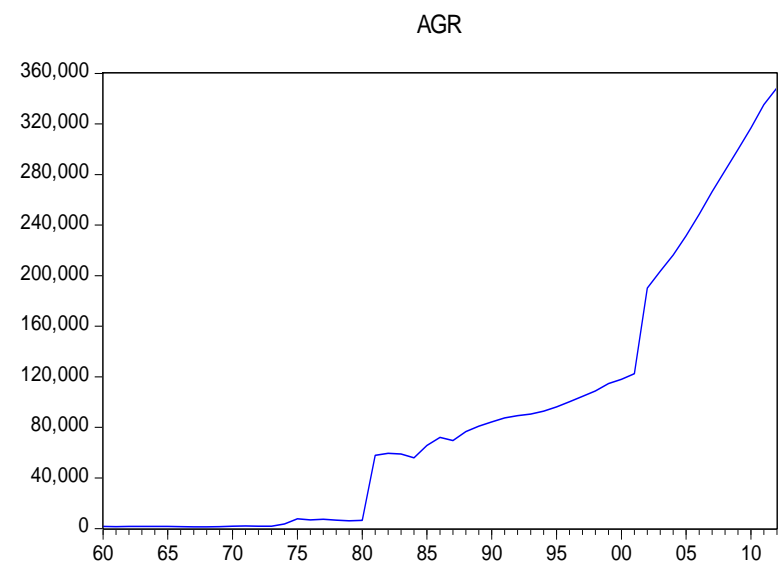

Figure. 1e

Figure 1a to 1e above show the trend analysis of all the variables which support the non stationary nature of the data series. Fig 1a shows that per capita income has increased from about 312 to 2,800 between 1960 to 2012, fig $1 \mathrm{~b}$ also shows the contribution of crude petroleum and gas output toward gross domestic product (GDP), this indicates that the product has increased from 11 in 1960 to about 122,317 in 2012 . The value of the solid minerals is shown in the fig $1 \mathrm{c}$ which indicate that it has also increased from about 20.6 in 1960 to 3,368.34 in 2012. Fig $1 \mathrm{~d}$ shows the result of the value of manufacturing sector which has increased from 114 in 1960 to $37,300.44$ in 2012. Finally, fig 1e shows the value agricultural output which has also increased fromabout 1600 in 1960 to 348,490.8 in 2012. These show that the values of all the variables were improved during the period of consideration and also were drastically improved after the transition of government in 1999 from military government to civilian except petroleum product. 
David, O. O., Noah, O. A., Agbalajobi, S. A.

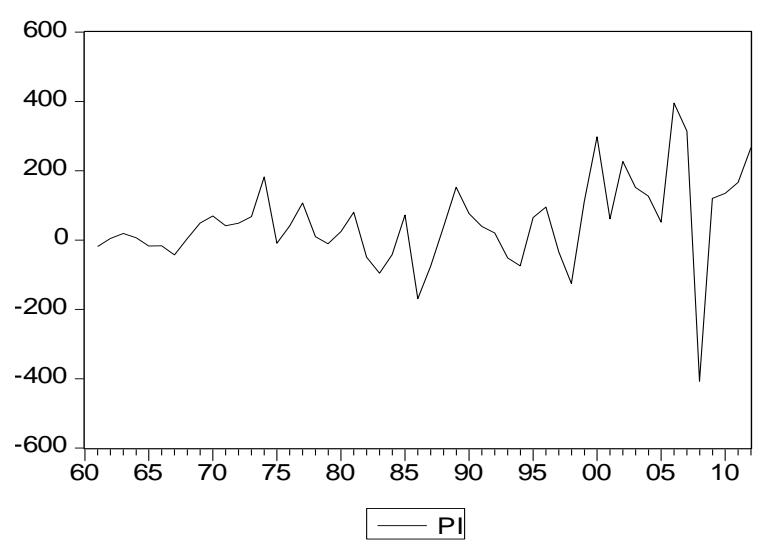

Figure. 2a

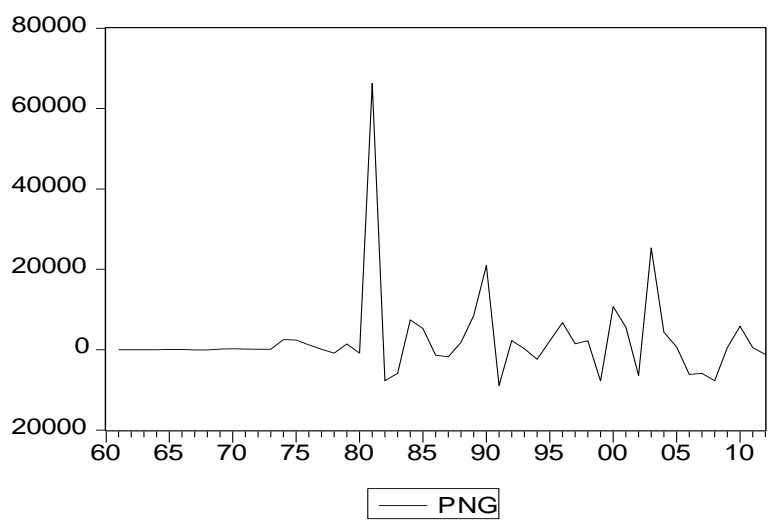

Figure. 2b

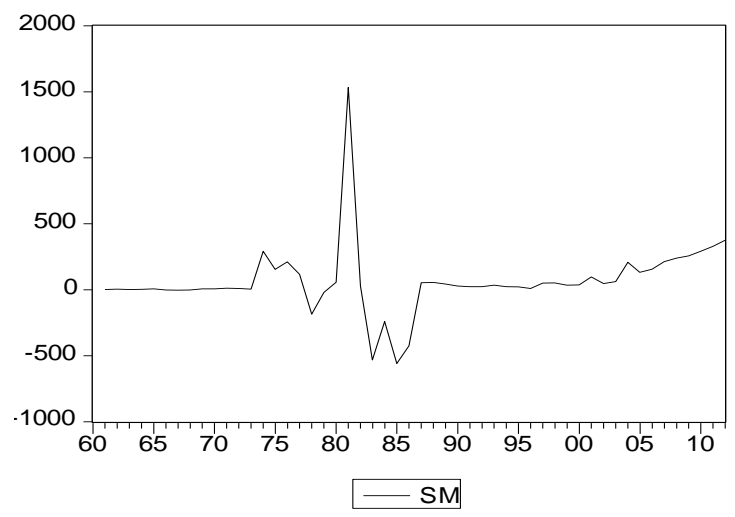


Figure. 2c

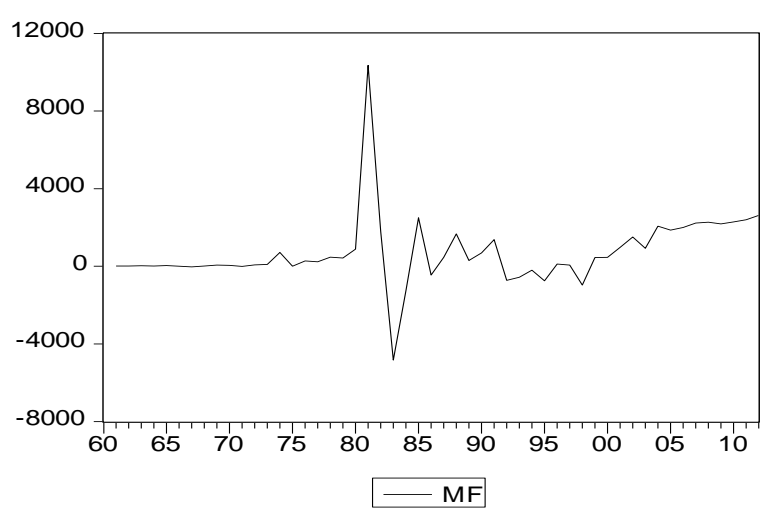

Figure. $2 d$

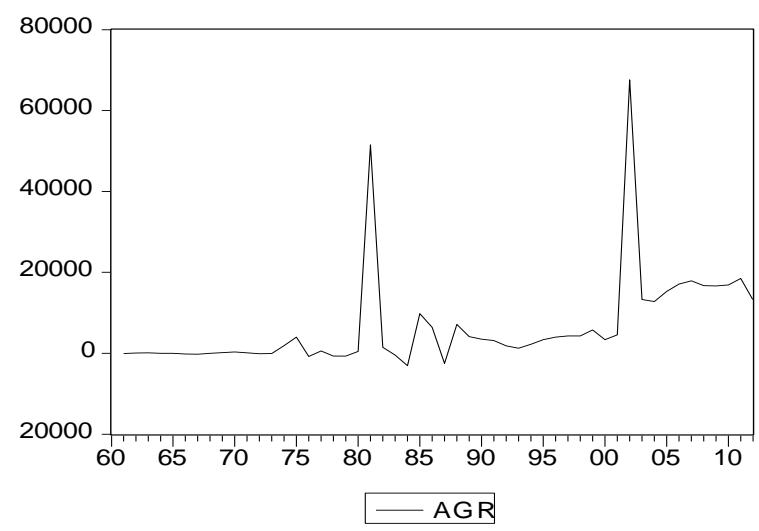

Figure. 2e

Figure $2 \mathrm{a}$ to $2 \mathrm{e}$ above show the trend analysis of all the variables which also support the stationary test. The results show that all the variables were relatively unstable except the value of agricultural output in the fig $2 \mathrm{e}$ which was drastically increased 1980 and 2002. For instance, fig 2a shows that per capital income decreased to about -500 in 2008 before it finally increased to about 300 in 2012. Fig $2 \mathrm{~b}$ also shows that the value of the crude petroleum product increased drastically in 1979 but later reduced to 0 in 2012. Fig 2c also shows that the value of the solid minerals increased to about 1,700 in 1980 which was later reduced to about 300 in 2012. Fig $2 d$ shows that the manufacturing sector increased to about 10,000 in 1980 and reduced back to about -5000 in 1983 and finally increased back 
to 2000. All these show the instability of all other sector except agricultural sector which is relatively stable.

Tab. 2 - Unit Root Test

\begin{tabular}{|c|c|c|c|}
\hline \multirow{3}{*}{ Variable } & \multicolumn{2}{|c|}{ Augmented Dickey Fuller (ADF) } & $\begin{array}{c}\text { Integration } \\
\text { Order }\end{array}$ \\
\cline { 2 - 4 } & LEVEL & FIRST DIFFERENCE & \\
\cline { 2 - 4 } & With Drift and Trend & With Drift and Trend & $\mathrm{I}(\mathrm{d})$ \\
\hline PI & -0.108210 & $-3.080248^{* * *}$ & $\mathrm{I}(1)$ \\
& $(0.9143)$ & $(0.0036)$ & \\
\hline PNG & $-2.154026^{* *}$ & $-3.798723^{* * *}$ & $\mathrm{I}(1)$ \\
& $(0.0369)$ & $(0.0005)$ & $\mathrm{I}(1)$ \\
\hline SM & -1.328215 & $-3.938344^{* * *}$ & $(0.0003)$ \\
\hline MF & $(0.1911)$ & $-3.217164 * * *$ & $\mathrm{I}(1)$ \\
& -1.126575 & $(0.0025)$ & $\mathrm{I}(1)$ \\
\hline AGR & $(0.2662)$ & $-3.278669^{* * *}$ & $(0.0021)$ \\
& 0.128676 & & \\
\hline
\end{tabular}

Source: Investigator's Computation, 2014.

Note: $* * *, * *$ and $*$ indicated at least significance at $1 \%, 5 \%$ and $10 \%$ level.

The unit root test is conducted through the Augmented-Dickey Fuller (ADF) approach as shown in Table 2 in which the empirical study discovered that the time series data of per capita income, value of solid mineral, value of manufacturing and value of agricultural products in Nigeria are not stationary at level but value of crude petroleum and gas in Nigeria is stationary at level but at 5 percent MacKinnon significance level. These suggest a further diagnosis of the data series and the study find out that per capita income, value of crude petroleum and gas, value of solid mineral, value of manufacturing and value of agricultural products in Nigeria are stationary at first difference at 1 MacKinnon percent significance level. In order to be certain of the order of integration of the data series, there is a need for Johansen Cointegrating tests.

Tab. 3 - Cointegration Test

\begin{tabular}{|l|c|c|c|c|c|}
\hline \multicolumn{7}{|c|}{ Johansen Cointegrating Tests } \\
\hline Eigen Values & 0.647309 & 0.541618 & 0.390933 & 0.316434 & 0.149514 \\
\hline Hypothesis & $\mathrm{r}=0$ & $\mathrm{r}=1$ & $\mathrm{r}=2$ & $\mathrm{r}=3$ & $\mathrm{r}=4$ \\
\hline Max-Eigen Test & $53.15030^{*}$ & $39.78265^{*}$ & $25.28714^{*}$ & $19.40202^{*}$ & $8.259286^{*}$ \\
& $(0.0004)$ & $(0.0031)$ & $(0.0364)$ & $(0.0231)$ & $(0.0041)$ \\
\hline 95\% critical value & 37.16359 & 30.81507 & 24.25202 & 17.14769 & 3.841466 \\
\hline
\end{tabular}




\begin{tabular}{|l|c|c|c|c|c|}
\hline Trace Test & $\begin{array}{c}145.8814^{*} \\
(0.0000)\end{array}$ & $\begin{array}{c}92.73109^{*} \\
(0.0000)\end{array}$ & $\begin{array}{c}52.94844^{*} \\
(0.0003)\end{array}$ & $\begin{array}{c}27.66130^{*} \\
(0.0019)\end{array}$ & $\begin{array}{c}8.259286^{*} \\
(0.0041)\end{array}$ \\
\hline $95 \%$ critical value & 79.34145 & 55.24578 & 35.01090 & 18.39771 & 3.841466 \\
& & & & & \\
\hline
\end{tabular}

Notes: VAR include one lag on each variables and a constant term. The estimated period is 1960-2012. None of the deterministic variable is restricted to the co-integration space and maximum Eigenvalue and Trace test statistics are adjusted for degrees of freedom. The critical values are taken from MacKinnon-Haug-Michelis (1999). The * indicates rejection of likelihood ratio tests at $5 \%$ significant level.

Johansen procedure is used to identify the long-run equilibrium in economic development amongst the cointegrating equations. Table 3 reports the estimates of Johansen procedure and standard statistics. In determining the number of cointegrating equations, the study used degrees of freedom adjusted version of the maximum-eigenvalue and trace statistics, since the existence of small samples with too many variables or lag Johansen procedure tends to overestimate the number of cointegrating equations. The Trace test statistics strongly rejects the null hypothesis of no cointegration in favour of five cointegration relationships while Max-Eigen test statistic rejects the null hypothesis of no cointegration in support of five cointegrating equations.

Tab. 4 - Economic Development Estimates for Long-run Equilibrium Relationship

Dependent Variable: PI

\begin{tabular}{|c|c|c|c|c|}
\hline Variable & Coefficient & $\mathrm{t}-$ ratio & $\mathrm{p}$ - value & Decision \\
\hline Constant & 400.5934 & 10.93375 & 0.0000 & - \\
\hline PNG & -0.000315 & -0.271060 & 0.7875 & $\begin{array}{c}\text { Accept } \mathrm{H}_{0} \\
\text { (Statistically Insignificant) }\end{array}$ \\
\hline SM & $0.292721 * * *$ & 4.606716 & 0.0000 & $\begin{array}{c}\text { Reject } \mathrm{H}_{0} \\
\text { (Statistically Significant) }\end{array}$ \\
\hline MF & $-0.029299 * *$ & -2.397377 & 0.0205 & $\begin{array}{c}\text { Reject } \mathrm{H}_{\mathbf{0}} \\
\text { (Statistically Significant) }\end{array}$ \\
\hline AGR & $0.007212 * * *$ & 9.547492 & 0.0000 & $\begin{array}{c}\text { Reject } \mathrm{H}_{0} \\
\text { (Statistically Significant) }\end{array}$ \\
\hline $\mathrm{R}^{2}=0.950165$ & \multicolumn{3}{|c|}{$\mathrm{F}=228.7952 * * *(0.000000)$} & $\mathrm{DW}=0.823766$ \\
\hline
\end{tabular}

Source: Investigator's Computation, 2014.

Note: $* * * * *$ and $*$ indicated at least significance at $1 \%, 5 \%$ and $10 \%$ level 
David, O. O., Noah, O. A., Agbalajobi, S. A.

Tab. 5 - Economic Development Estimates for Short-run Equilibrium Relationship Dependent Variable: $\Delta P I$

\begin{tabular}{llllc|}
\hline Variable & Coefficient & $\mathrm{t}-$ ratio & $\mathrm{p}$ - value & Decision \\
Constant & 18.69815 & 1.007483 & 0.3190 & - \\
$\Delta \mathrm{PNG}$ & -0.001503 & -0.758299 & 0.4521 & $\begin{array}{c}\text { Accept } \mathrm{H}_{0} \\
\text { (Statistically Insignificant) }\end{array}$ \\
$\Delta \mathrm{SM}$ & 0.105713 & 0.973788 & 0.3353 & $\begin{array}{c}\text { Accept } \mathrm{H}_{0} \\
\text { (Statistically Insignificant) }\end{array}$ \\
$\Delta \mathrm{MF}$ & 0.008315 & 0.483036 & 0.6314 & $\begin{array}{c}\text { Accept } \mathrm{H}_{0} \\
\text { (Statistically Insignificant) } \\
\text { Reject } \mathrm{H}_{0}\end{array}$ \\
$\Delta \mathrm{AGR}$ & 0.002956 & $1.691556 *$ & 0.0975 & $\begin{array}{c}\text { (Statistically Significant) } \\
\text { Reject } \mathrm{H}_{0}\end{array}$ \\
$\mathrm{ECM}(-1)$ & -0.328285 & $-2.816919 * * *$ & 0.0071 & (Statistically Significant) \\
\hline $\mathrm{R}^{2}=0.254326$ & \multicolumn{2}{c}{$\mathrm{F}=3.137833^{2} *(0.016103)$} & DW $=1.640855$ \\
\hline
\end{tabular}

Source: Investigator's Computation, 2014.

Note: $* * *, * *$ and $*$ indicated at least significance at $1 \%, 5 \%$ and $10 \%$ level

\subsection{Discussion of the Results}

The Economic Development models were estimated in the long run and short run equilibrium through Ordinary Least Squares (OLS) and Fully Modified Ordinary Least Squares (FMOLS) techniques respectively. The results as depicted in Table 4 and Table 5 show that economic development (per capita income) in the long run and short run is positively associated with Value of Solid Mineral and Value of Agriculture over the scope of the study, 1960 - 2012 in Nigeria. But, Per capita income is inversely related to Value of Crude Petroleum and Gas in the both long and short run equilibrium. While, Per capital income is inversely related to Value of Manufacturing in the long run equilibrium but directly related to Value of Manufacturing in the short run equilibrium. And, the Error Correction Mechanism (ECM) is inversely related to per capita income in Nigeria which follows the a priori expectation.

The empirical result in the long run equilibrium shows that Value of Solid Mineral, Value of Manufacturing and Value of Agriculture are statistically significant atleast at 5 percent significance level but Value of Crude Petroleum and Gas is statistically insignificant in the long and short run equilibrium. The short run effect reveals that it is only Value of Agriculture that exerts statistical importance atleast at 10 percent to per capita income in Nigeria for the period under investigation. 
The variation causation effect of the exact components (Value of Crude Petroleum and Gas, Value of Solid Mineral, Value of Manufacturing and Value of Agriculture) on economic development (Per Capita Income) in Nigeria are ascertained at $95.0165 \%$ and $25.4326 \%$, both at the long run and short run respectively, while the inexact components (error term) are responsible for $4.9835 \%$ and $74.5674 \%$ variations in economic development respectively in Nigeria. These indicate that it is only in the long run that Value of Crude Petroleum and Gas, Value of Solid Mineral, Value of Manufacturing and Value of Agriculture caused more variations to economic development (per capita income) in Nigeria but not as immediate. The overall significance of the model is carried out through analysis of variance (ANOVA) in the long run equilibrium i.e. $\mathrm{F}$ test. The result shows that the $\mathrm{F}$ values is 228.7952 which is significant at $1 \%$ (i.e. $0.00000<0.01$ ) with degree of freedom $\mathrm{V}_{1}=\mathrm{K}-1=5-1=4$ and $\mathrm{V}_{2}=\mathrm{N}-\mathrm{K}=53-5=48$. This is used to evaluate the research hypothesis statements that $\mathrm{H}_{0}=$ Mining sector does not have contribution to economic development in Nigeria and $\mathrm{H}_{1}=$ Mining sector have contribution to economic development in Nigeria. Based on the ANOVA result that $\mathrm{p}$ value $(0.000000)$ is less than 0.01 , reject the null hypothesis and we conclude that Mining sector have contribution to economic development in Nigeria from 1960 - 2012. The autocorrelation test is carried out through the DurbinWatson test in which the values are 0.823766 and 1.640855 in the long and short run equilibrium respectively. If the Durbin-Watson is far less and more than 2, there is existence of serial correlation. The Durbin-Watson's results for this study is approximately equals to 2 in the short run equilibrium and we conclude that there is no existence of autocorrelation in the economic development model in the short run equilibrium but there is existence of serial correlation in the long run in Nigeria.

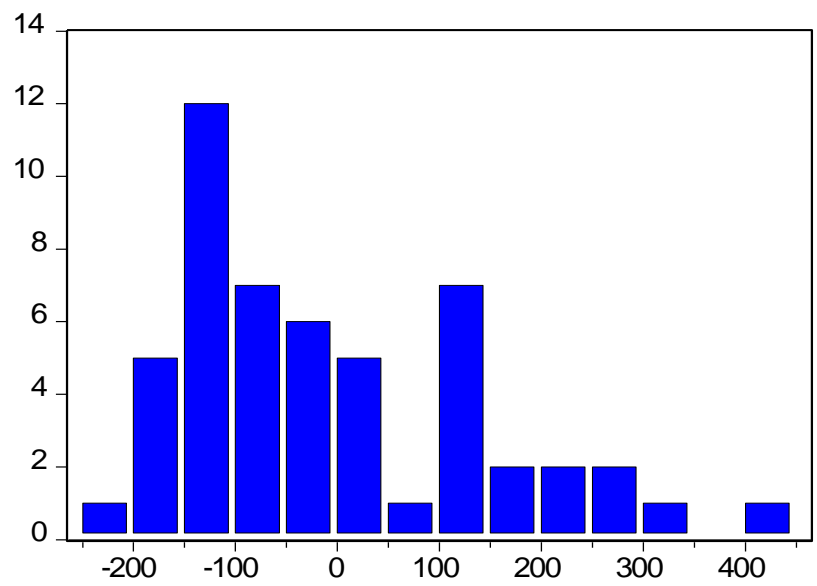

Series: ECM

Sample 19612012

Observations 52

Mean

$-0.665469$

Median

$-45.21469$

Maximum

434.7375

Minimum

$-249.2839$

Std. Dev.

151.0057

Skewness $\quad 0.863755$

Kurtosis

3.117126

Jarque-Bera $\quad 6.495685$

Probability

0.038858

Figure. 3 - Normality Test for Error Term 
This test is used to detect the normality of the error term from OLS estimation. Using the estimated residuals from the regression, the information is given in Fig. 3. As the figure shows, the residuals from the economic development regression are symmetrically distributed. Application of the Jarque-Bera test shows that the JB statistic is about 6.495685 , and the probability of obtaining such a statistic under the normality assumption is about $3.8858 \%$. Thus, the error term are normally distributed and signifies stationarity of the time series data used for the equilibrium estimation. Therefore, we conclude do not reject the hypothesis that the error terms are normally distributed.

\section{CONCLUSION AND RECOMMENDATIONS}

Solid minerals have the potential to contribute significantly to the economic development of a country. Mining can create significant economic benefits which include the direct benefits that come in the form of income and employment, as well as the indirect benefits that come in the form of local or international purchase of mining inputs. Therefore, results from this empirical analysis provide strong evidence indicating that the value of solid mineral and other specified sectors (value of agriculture, value of crude petroleum and gas and value of manufacturing) have a great contribution toward economic development in Nigeria. Specifically, the results also suggest thateconomic development (per capita income) in the long run and short run is positively associated with value of solid mineral and value of agriculture over the scope of the study. But, Per capita income is inversely related to value crude petroleum and gas in the both long and short run equilibrium, the reason for this maybe as a result of the fact that the petroleum sector is largely operated by the expatriate while it employed few Nigerians. This study therefore provides evidence in support of increasing public and private resources allocated to mining development in Nigeria. Government should come out with stable policy guideline that will create enabling environment for the private sector to invest more in mining sector, ensure transparency, accountability and monitoring of compliance with mining laws and regulations so that mining sector can be used to create jobs and wealth for the country and as well as diversification of Nigerian economy. 


\section{References and notes:}

Adekeye, J.I.D. (1999). Solid Minerals Development: Nigeria's Economic Mirage. Earth Sciences Research Communications 1(1): pp. 10 - 24. Published by Research Communications, Lagos.

Adekeye, J.I.D. (2010). Impact of Conflict on Mining in Nigeria. In I.O. Albert and O.N.Olarinde (eds). Trends and Tensions inManaging Conflicts. Society for Peace Studiesand Practice (SPSP). Ibadan, Nigeria. P. 254-263.

Adeniyi, I. O., Adeleke, M.O.,\& Olabode, O. A. (2013). Legal Regime for Exploring SolidMinerals for Economic Growth in Nigeria. Journal of Canadian Social Science. Vol. 9,No. 5, 2013, pp. 67-77

Akongwale, S., Ayodele,O.S., \&Udefuna, .P.N (2013). Economic Diversification in Nigeria: AnyRole forSolid Mineral Development? Mediterranean Journal of Social SciencesPublished by MCSER-CEMAS-SapienzaUniversity of Rome. Vol 4 No 6, pp. 691-703

Alison-Madueke, D. (2009). Opportunities in Nigeria's Minerals Sector. Ministry of Mines And Steel Development, Abuja, Nigeria, 22nd April 2009.

Belshaw, D. \& Livingstone, I. (2002). Reviewing Development in Sub-Saharan Africa: Policy, Performance and Prospects. London: Routledge.

Bridge, G. (2008). Economic geography: natural resources. In: International Encyclopaedia ofHumanGeography.Eds. Kitchin and Thrift. Elsevier.

Malizia, E. E. \& Fesser, E. J. (2000). Understanding Economic Development. London: Rutgers.Martin, X.S. and A. Subramanian (2003); "Addressing the Natural Resource Curse: An illustration from Nigeria". NBER Working Paper No. 9804

Jhingan, M.L. \& Sharma C. K. (2008). Environmental Economics: Theory, Management and Policy.Indian, Vrinda Publications (P) Ltd.

Giran N. (1971), "Foreign Capital and Economic Underdevelopment in Jamaica", Institute

Of Social and EconomicResearch, University of the West Indies, Kingston.

Hoyt, H. (1939), Evans, P. (1975), Dependent Development: The Alliance of Multinationals, State and LocalCapital inBrazil, (Princeton, NJ; Princeton University Press).

Reynolds,CN. (1979), "Bankers as Revolutionaries in the Process of Development", in J. D.Aronson(eds.), Debtand the Less Developed Countries. (Boulder Colo.: Westview Press).

Roderick G. E. (2001). Mining and Economic Sustainability: National Economies and LocalCommunities.Division of Economics and Business, Colorado School of Mines, US. 


\title{
Summary
}

\section{An Empirical Analysis of the Contribution of Mining Sector to Economic Development in Nigeria}

\author{
David, Oladipo Olalekan \\ University of South Africa, Pretoria, South Africa \\ Noah, Oluwashina Afees \\ Kwara State Polytechnic, Ilorin, Nigeria
}

Agbalajobi, Sunday Ayodele

Kwara State Polytechnic, Ilorin, Nigeria

\begin{abstract}
Nigeria is richly endowed with vast but largely untapped natural resources including solid minerals and arable land. Mining industries have been viewed as key drivers of economic growth and development process, as lead sectors that drive economic expansion which can lead to higher levels of social and economic well being. Contributions from mining as a percentage of GDP in rich countries are usually between 2-8 percent. In Nigeria, the contribution is still low at 0.15 percent, one of the major factors responsible for this is as a result of over dependence of the Nigerian economy on the proceeds from the sale of crude oil for over four decades which is at the expense of other sectors such as mining and agriculture that contributed significantly to the Nigerian economy before the emergence of crude oil. In the light of this, the study presents an empirical analysis of the contribution of mining sector to the economic development in Nigeria from 1960 to 2012. The study employed Error Correction Model (ECM) to examine the short run and long run effect of mining sector's contribution to Nigeria economic development. The study harnessed time series data to evaluate the impact of the specified key sectors; crude petroleum and gas, solid mineral, manufacturing and agriculture on the economic development proxied by per capita income. Equally highlighted are the problems militating against the mining sector in Nigeria and the strategies for its transformation of the economy. The finding revealed that the value of solid mineral have strong impact on economic development in Nigeria. Thus, Nigeria needs to urgently develop her monumental mining potentials in order to diversify her economy and to achieve rapid economic growth and development.
\end{abstract}

Keywords: Mining, Economic Development, Error Correction Model (ECM) 